\title{
Three new genera from South America and some taxonomic changes in Gyponini (Insecta: Hemiptera: Cicadellidae)
}

\author{
Clayton C. GONÇALVES ${ }^{1, *}$, Alexandre C. DOMAHOVSKI ${ }^{2}$, \\ Gabriel MEJDALANI ${ }^{3} \&$ Daniela M. TAKIYA ${ }^{4}$ \\ ${ }^{1,4}$ Laboratório de Entomologia, Departamento de Zoologia, Instituto de Biologia, Universidade Federal \\ do Rio de Janeiro, Caixa Postal 68044, Rio de Janeiro, 21941-971, RJ, Brazil. \\ ${ }^{2}$ Departamento de Zoologia, Universidade Federal do Paraná. Caixa Postal 19020, \\ Curitiba, 81531-980, PR, Brazil. \\ ${ }^{3}$ Departamento de Entomologia, Museu Nacional, Universidade Federal do Rio de Janeiro, \\ Rio de Janeiro, 20940-040, RJ, Brazil. \\ ${ }^{*}$ Corresponding author: clayton.correa.goncalves@gmail.com \\ ${ }^{2}$ Email: domahovskiac@yahoo.com.br \\ ${ }^{3}$ Email: mejdalan@acd.ufrj.br \\ ${ }^{4}$ Email: takiya@acd.ufrj.br \\ ${ }^{1}$ urn:1sid:zoobank.org:author:41E6BE64-C8CD-4BAF-86AA-272CF5BE88C5
${ }^{2}$ urn:1sid:zoobank.org:author:0B988BD5-599B-42CE-ADCB-50FC813E104E
${ }^{3}$ urn:1sid:zoobank.org:author:DE1C60FA-FB28-4F73-B316-18E901D5783D
${ }^{4}$ urn:lsid:zoobank.org:author:7E88BC1C-8D6A-411D-B97B-52E64EF5BA70
}

Abstract. Three new South American leafhopper genera of the tribe Gyponini are proposed: Beltrana gen. nov. based on Beltrana reticulata gen. et sp. nov. from French Guiana, Fulana gen. nov. based on Fulana brasiliensis gen. et sp. nov. from Brazil, and Sicrana gen. nov. based on Sicrana plana gen. et sp. nov. from Brazil and Ecuador. Diagnoses, detailed descriptions, and illustrations are provided for each taxon, as well as comparisons with closely related genera. In addition, the following synonyms are proposed: Freytagana DeLong, 1975 as a junior synonym of Marganana DeLong, 1948 and F. gibsoni DeLong, 1975 as a junior synonym of M. (Marganana) mexicana DeLong \& Freytag, 1963. Chilella DeLong \& Freytag, 1967 is transferred from Gyponini to Selenomorphini Evans, 1974.

Keywords. Beltrana, Fulana, leafhoppers, Sicrana, taxonomy.

Gonçalves C.C., Domahovski A.C., Mejdalani G. \& Takiya D.M. 2021. Three new genera from South America and some taxonomic changes in Gyponini (Insecta: Hemiptera: Cicadellidae). European Journal of Taxonomy 750: 70-93. https://doi.org/10.5852/ejt.2021.750.1363

\section{Introduction}

Gyponini Stål, 1870 is the most diverse of the twelve tribes of Iassinae Walker, 1870 (Krishnankutty et al. 2016). DeLong \& Freytag (1964), based on the diversity known at that time, suggested that Gyponini 
could include more than 500 species. Currently, considering the recently described taxa, the tribe comprises 1405 species in 71 genera (Domahovski \& Cavichioli 2020, 2021; Domahovski et al. 2020; Freytag 2021). Based on the large number of undescribed species deposited in Brazilian collections, we believe that the diversity of Gyponini will exceed 2000 species. Specimens can be collected using sweeping nets and sometimes yellow plates; however, light and Malaise traps are the most effective methods for collecting these leafhoppers (Domahovski \& Cavichioli 2018).

This paper proposes the establishment of three new Gyponini genera, with very peculiar morphological features: Beltrana gen. nov. from French Guiana, Fulana gen. nov. from Brazil, and Sicrana gen. nov. from Brazil and Ecuador. The names "Fulana, Beltrana, and Sicrana" form a Portuguese expression equivalent to the English expression "Tom, Dick, and Harry". This expression is used to refer to multiple unspecified people. The names were chosen because this expression is very popular in Brazil and, also, they end in '-ana' which is a common suffix in most generic names of Gyponini.

In addition, the following synonyms are proposed: Freytagana DeLong, 1975 as a junior synonym of Marganana DeLong, 1948 and F. gibsoni DeLong, 1975 as a junior synonym of M. (Marganana) mexicana DeLong \& Freytag, 1963. Chilella DeLong \& Freytag, 1967 is transferred from Gyponini to Selenomorphini Evans, 1974.

\section{Material and methods}

Specimens studied herein are deposited in the following collections:

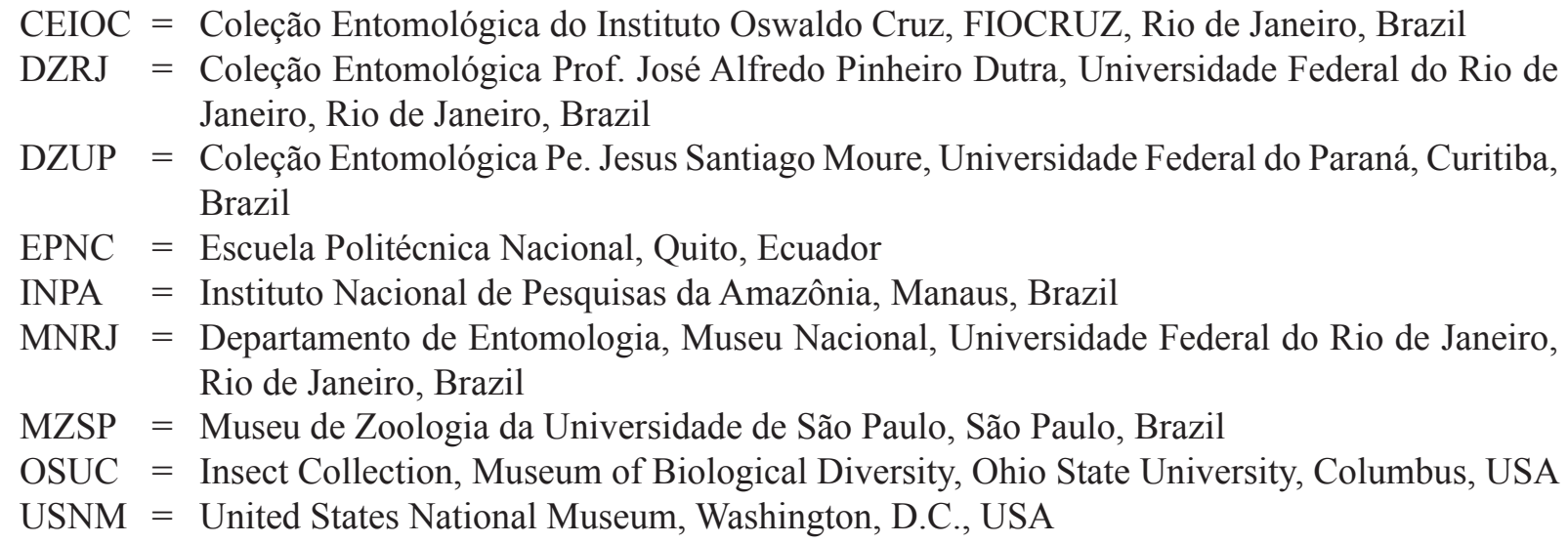

Terminology mainly follows Young $(1968,1977)$, except for head features (Hamilton 1981; Mejdalani 1993, 1998), wings (Dietrich 2005), and leg chaetotaxy (Rakitov 1997). Techniques used for dissection of the male terminalia follow Oman (1949), with a few modifications described by Cavichioli \& Takiya (2012). Female terminalia were prepared according to the techniques of Zanol (1988) and Mejdalani (1998). Square brackets [ ] in material label data were used to supplement abbreviated information. 


\title{
Results
}

\section{Taxonomic treatments}

\author{
Class Insecta Linnaeus, 1758 \\ Order Hemiptera Linnaeus, 1758 \\ Suborder Auchenorrhyncha Duméril, 1806 \\ Family Cicadellidae Latreille, 1825 \\ Subfamily Iassinae Walker, 1870 \\ Tribe Gyponini Stål, 1870 \\ Genus Beltrana gen. nov. \\ urn:1sid:zoobank.org:act:4C0DFFC6-7F48-457C-97C6-361C182A69DC \\ Figs 1, 6A-B
}

\section{Type species}

Beltrana reticulata gen. et sp. nov., by present designation and monotypy.

\section{Diagnosis}

Medium-sized leafhoppers (Fig. 6A-B). Head in dorsal view (Fig. 1A) moderately produced anteriorly, median length of crown slightly less than interocular width; in lateral view (Fig. 1C), with crown-face transition with anterior margin foliaceous and bicarinate. Forewing (Fig. 1D) with venation densely reticulated, appendix very narrow. Male pygofer (Fig. 1F) without membranous apical digitiform process. Subgenital plate (Fig. 1F, H) fully sclerotized. Aedeagus (Fig. 1K-L) simple, without apodemal processes.

\section{Etymology}

The generic name is feminine. Beltrana, together with Fulana and Sicrana, forms a very popular expression in Brazil ("Fulana, Sicrana e Beltrana"), which refers to unspecified people or people whose actual names should not be mentioned.

\section{Description}

Head AND thorax. Head in dorsal view (Fig. 1A) moderately produced anteriorly, median length of crown slightly less than interocular width; transocular width about six-sevenths humeral width of pronotum; crown with anterior margin broadly rounded, surface mostly flat, slightly concave medially, with subtle oblique striae between ocelli and adjacent to anterior margin; ocellus medium-sized, equidistant between median line and eye margin, closer to posterior than anterior margin of crown; coronal suture distinct only on basal portion of crown. Head in ventral view (Fig. 1B) with face slightly higher than wide; frontogenal suture distant from eye margin by slightly less than maximum width of clypeus and extending to anterior margin of crown; antennal ledge carinated and adjacent to anterior margin of crown, obliquely ascending and not extending over frons; frons approximately 1.7 times as long as wide; epistomal suture indistinct; clypeus approximately 1.3 times as long as maximum width, lateral margins parallel, apex slightly emarginated; maxillary plate produced ventrally, not reaching clypeus apex; gena excavated just below eye, ventrolateral margin slightly excavated. Head in lateral view (Fig. 1C) with crown-face transition distinct and foliaceous, with two carinae; frons concave below anterior margin of crown. Pronotum (Fig. 1A) with transverse striae on disc and posterior half; lateral margins straight, convergent anterad, and approximately as long as eye length; posterior margin excavated; in lateral view (Fig. 1C), moderately declivous, continuous with head declivity. Mesonotum (Fig. 1A) longer than wide; scutellum (Fig. 1C) flat. Forewing (Fig. 1D) hyaline, long, and narrow, approximately 3.2 times as long as maximum width; venation distinct and densely reticulated; appendix 
very narrow. Profemur with $\mathrm{AD}, \mathrm{AM}$, and $\mathrm{PD}$ rows reduced and poorly defined, with exception of apical setae $\mathrm{AD}_{1}, \mathrm{AM}_{1}$, and $\mathrm{PD}_{1}$, respectively; $\mathrm{AV}$ and $\mathrm{PV}$ rows formed by 4-5 setae; IC row formed by slightly arched comb of fine setae, beginning at distal third of femur and extending to $\mathrm{AM}_{1}$. Protibia, in cross-section, semi-circular; AV row formed by long setae, slightly longer and thicker towards apex; $\mathrm{AD}$ and $\mathrm{PD}$ rows without differentiated setae; PV row with 5 setae. Metafemur with setal formula 2:2:1. Metatibial AD row without intercalary setae between macrosetae; PD, AD, and AV rows with 26-28, 13-14, and 19-20 macrosetae, respectively. Metatarsomere I with outer setal row indistinct, apex with 5 platellae. Metatarsomere II apex with 4 platellae.

Male terminalia. Pygofer (Fig. 1F) without membranous apical digitiform process. Subgenital plate (Fig. 1F, H) fully sclerotized. Connective (Fig. 1I) T-shaped. Aedeagus (Fig. 1K-L) simple, without apodemal processes.

Female terminalia. Female unknown.

\section{Distribution}

French Guiana.

\section{Remarks}

An unpublished phylogenetic hypothesis based on 182 morphological characters combined with sequence data (28S and $16 \mathrm{~S}$ rDNA and cytochrome oxidase subunit I) recovered Beltrana gen. nov. as the sister group of the clade Reticana DeLong \& Freytag, 1964 + Chloronana DeLong \& Freytag, 1964 (Gonçalves 2016). Beltrana gen. nov. shares the following morphological characteristics with Reticana and Chloronana: (1) green coloration in life, yellow when preserved; (2) crown moderately produced anteriorly; (3) crown-face transition distinct and foliaceous; (4) forewing with venation reticulated; (5) metatibia without intercalary setae between macrosetae in AD row; (6) style short and with apical denticles; and (7) aedeagus with shaft long, thin, and with apical processes. However, Beltrana gen. nov. can easily be distinguished from Reticana and Chloronana by its more robust body (Fig. 6A); forewing more densely reticulated (Fig. 1D); male pygofer without membranous apical digitiform process (Fig. 1F); and subgenital plate fully sclerotized (Fig. 1F, H).

Beltrana reticulata gen. et sp. nov.

urn:1sid:zoobank.org:act:2F33353D-4741-476E-B6A8-FA2F74B33A35

Figs 1, 6A-B

\section{Diagnosis}

Pygofer (Fig. 1F) with apex distinctly truncated, ventral margin expanded posteroventrally, forming subquadrate lobe; in dorsal view (Fig. 1G), with small preapical inner lobe. Subgenital plate (Fig. 1F, H) with small sclerotized dorsal tooth near apex. Style (Fig. 1I-J) with knob-shaped apex bearing numerous denticles. Aedeagus (Fig. 1K-L) with pair of short and acute apical processes.

\section{Etymology}

The specific epithet alludes to the reticulated venation of forewing (Fig. 1D).

\section{Material examined}

Holotype

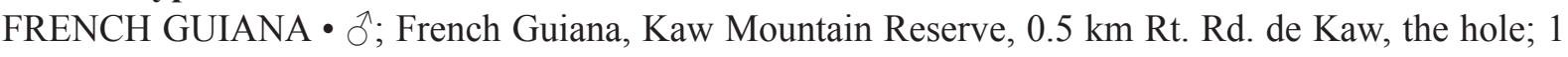
Feb. 2008; H. Romack leg.; DNA voucher Entomologia, DZRJ ENT 2812; USNM. 

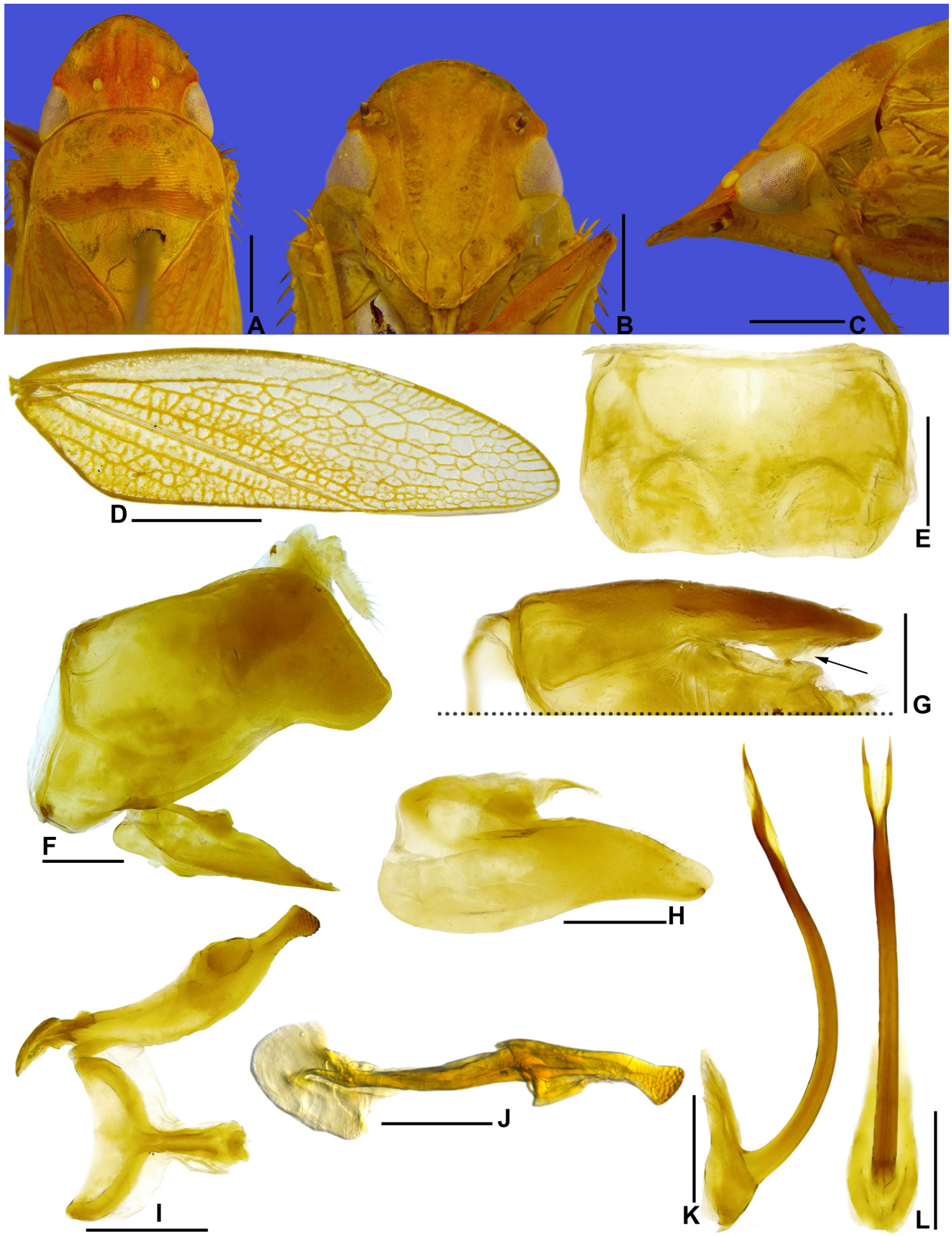

Fig. 1. Beltrana reticulata gen. et sp. nov., holotype, $\widehat{o}$ (USNM). A. Head and thorax, dorsal view. B. Head, ventral view. C. Head and thorax, lateral view. D. Forewing. E. Sternite VIII. ventral view. F. Pygofer, anal tube, valve, and subgenital plate, lateral view. G. Pygofer lobe and anal tube, dorsal view (arrow indicates the inner lobe). H. Subgenital plate, ventral view (outer margin at top of figure). I. Style and connective, dorsal view. J. Style, lateral view. K. Aedeagus, lateral view. L. Aedeagus, posterior view. Scale bars: $\mathrm{A}-\mathrm{C}=1.0 \mathrm{~mm} ; \mathrm{D}=2.0 \mathrm{~mm} ; \mathrm{E}-\mathrm{L}=0.5 \mathrm{~mm}$. 


\section{Paratype}

FRENCH GUIANA・ 1 ; same collection data as for holotype; DZRJ-AUCH \#249; DZRJ.

\section{Description}

MeAsurements. Total length: male 12.3-12.5 mm $(\mathrm{n}=2)$.

Coloration. Yellow (Fig. 6A-B). Crown (Fig. 1A) mostly orange, anterior and posterior margins yellow; ocelli yellow. Pronotum (Fig. 1A) with anterior three-fourths yellow and posterior fourth dark yellow. Forewing (Fig. 1D) yellow, translucent, with dark yellow venation. Legs (Fig. 6B) yellow.

HeAd And Thorax. External morphological characters as in generic description.

Male terminalia. Sternite VIII (Fig. 1E) subrectangular, about 1.5 times as wide as long; lateral margins slightly rounded; posterior margin rectilinear. Pygofer in lateral view (Fig. 1F) trapezoidal, length approximately twice maximum height; apex distinctly truncated; macrosetae distributed only near apex, presence of few short and robust setae near apex; ventral margin expanded posteroventrally, forming subquadrate lobe; in dorsal view (Fig. 1G), with small preapical inner lobe. Subgenital plate in lateral view (Fig. 1F) not produced posteriorly as far as pygofer apex; in ventral view (Fig. 1H), subtriangular, basal half of external margin expanded laterally, bearing short setae on apical half; apical half narrowing progressively towards apex; internal margin sinuous; dorsal surface with small, sclerotized tooth near apex; apex rounded. Connective (Fig. 1I) approximately three-fifths of length of style; arms broad. Style (Fig. 1I), in dorsal view, with apodeme very short, spatulate, and strongly flattened laterally; apophysis elongated, flattened laterally; dorsal margin expanded laterally, forming preapical lamella; in lateral view (Fig. 1J), outer lobe indistinct; apex sclerotized, knob-shaped, with numerous small lateral and ventral denticles. Aedeagus (Fig. 1K-L) with preatrium reduced; dorsal apodeme developed dorsally, not expanded laterally; shaft tubular and very elongated, curved anteriorly; apex with pair of short and acute processes directed dorsally.

Female terminalia. Female unknown.

Genus Fulana gen. nov. urn:lsid:zoobank.org:act:D3D2E937-9B40-42BB-AAC4-F821B4D22CB5

Figs $2-3,6 \mathrm{C}-\mathrm{F}$

\section{Type species}

Fulana brasiliensis gen. et sp. nov., by present designation and monotypy.

\section{Diagnosis}

Medium-sized leafhoppers (Fig. 6C-F). Head in dorsal view (Fig. 2A) short, median length of crown about 2.5 times smaller than interocular width; crown transversely striated; ocellus large, closer to anterior margin of crown; in lateral view (Fig. 2C), with crown-face transition distinct and narrow, bicarinate. Pronotum (Fig. 2A) with punctures. Forewing (Fig. 2D) covered by numerous small brown spots, appendix narrow. Male pygofer (Fig. $2 \mathrm{~F}-\mathrm{G}$ ) with inner basiventral process; lateral lobe partly separated from base by flexible membranous line. Subgenital plate (Fig. $2 \mathrm{H}$ ) with ventral surface covered by long filiform setae. Connective (Fig. 2I) longitudinally linear. Aedeagus (Fig. 2K-L) simple, without apodemal processes. Second valvula of ovipositor (Fig. 3G-H) with few teeth restricted to apical fourth. 


\section{Etymology}

The generic name is feminine. Fulana, together with Beltrana and Sicrana, forms a very popular expression in Brazil ("Fulana, Sicrana e Beltrana"), which refers to unspecified people or people whose actual names should not be mentioned.

\section{Description}

HeAd And Thorax. Head in dorsal view (Fig. 2A) short; median length of crown about 2.5 times smaller than interocular width; crown with anterior margin slightly sinuous; surface adjacent to ocelli slightly concave between ocellus and eye; texture transversely striated; transocular width of head six-sevenths of humeral width of pronotum; ocellus large, close to anterior margin of crown and slightly closer to eye than to median line; coronal suture distinct, extending to near anterior margin of crown. Head in ventral view (Figs 2B, 3A) with face wider than high; frontogenal suture distant from eye margin by basal width of clypeus and surpassing antennal ledge, extending to anterior margin of crown; oriented obliquely downward in relation to frons; frons approximately as wide as long, lateral margins strongly convergent ventrally; epistomal suture distinct; clypeus approximately 1.2 times as long as maximum width, lateral margins divergent apically, apex slightly emarginated; maxillary plate produced ventrally as far as clypeus apex; gena with ventrolateral margin straight on mid-length and slightly excavated below eye margin. Head in lateral view (Fig. 2C) with crown-face transition distinct and narrow, bicarinate; frons and clypeus flattened. Pronotum (Fig. 2A) with conspicuous transverse striae and punctures on disc and posterior half; lateral margins straight, convergent anterad, slightly shorter than eye length; posterior margin straight; in lateral view (Fig. 2C), moderately declivous; head and pronotum in continuous slope. Mesonotum (Fig. 2A) as long as wide; scutellum (Fig. 2C) slightly swollen. Forewing (Fig. 2D) translucent, covered by numerous small brown spots; long and narrow, approximately 3.3 times as long as wide; venation distinct; appendix very narrow and bordering first to second apical cells. Profemur with $\mathrm{AD}, \mathrm{AM}$, and $\mathrm{PD}$ rows reduced and poorly defined, with exception of apical setae $\mathrm{AD}_{1}, \mathrm{AM}_{1}$, and $\mathrm{PD}_{1}$, respectively; $\mathrm{AV}$ and PV rows formed by $2-3$ setae; IC row formed by slightly arched comb of fine setae, beginning at distal half of femur and extending to $\mathrm{AM}_{1}$. Protibia in cross-section semi-circular; $\mathrm{AV}$ row formed by long setae, slightly longer and thicker towards apex; AD row without differentiated setae; PD row with 7-8 setae; PV row with 6-7 setae. Metafemur with setal formula 2:2:1. Metatibia PD, AD, and AV rows with 26-31, 13-14, and 16-19 macrosetae, respectively; AD row with 1-4 intercalary setae between macrosetae; PV row with setae of apical half formed by sequence of a thicker and 2-4 thinner setae. Metatarsomere I with two rows of setae, inner row consisting of larger and more robust setae than those of outer row; apex with 6 platellae; metatarsomere II apex with 2-3 platellae.

Male terminalia. Sternite VIII (Fig. 2E) long, fully hiding subgenital plates. Pygofer (Fig. 2F-G) with inner basiventral process adjacent to ventral margin; lobe partly separated from base by flexible membranous cleft. Subgenital plate (Fig. $2 \mathrm{H}$ ) with ventral surface covered by long filiform setae. Connective (Fig. 2I) longitudinally linear. Aedeagus (Fig. 2K-L) simple, without apodemal processes.

Female terminalia. Second valvula of ovipositor (Fig. 3G) elongated, slightly higher along apical fourth; apical portion (Fig. $3 \mathrm{H}$ ) with dorsal margin bearing minute and uniform denticles.

\section{Distribution}

Brazil (Bahia, Minas Gerais, Paraná, Rio de Janeiro, Santa Catarina, and São Paulo states).

\section{Remarks}

An unpublished study based on 182 morphological characters combined with sequence data (28S and 16S rDNA and cytochrome oxidase subunit I) recovered Fulana gen. nov. as the sister group to all other gyponines except Chilenana DeLong \& Freytag, 1967 (Gonçalves 2016). In fact, the genera Fulana 
gen. nov. and Chilenana share plesiomorphic characteristics with other tribes of Iassinae, which are absent in other Gyponini genera: (1) male pygofer with lateral lobe partly separated from base by flexible membranous cleft; and (2) presence of basiventral inner process on the male pygofer.

The new genus resembles Alapona DeLong, 1980, Ponana Ball, 1920, and Dumorpha DeLong \& Freytag, 1975 because of its slightly anteriorly produced and transversely striated crown; ocellus closest to the anterior margin of the crown; forewing with dark spots; and metatibia with intercalary setae between macrosetae of the AD row. However, Fulana gen. nov. differs from Alapona by the lack of flaps in the aedeagus (Fig. 2K-L), from Ponana and Alapona by its thinner crown-face transition (Fig. 2C), and from Ponana and Dumorpha by its aedeagus without apodemal processes (Fig. 2K).

Fulana brasiliensis gen. et sp. nov. urn:1sid:zoobank.org:act:B1D1E77B-63FF-443C-8AEC-9952CA62AFAE

Figs $2-3,6 \mathrm{C}-\mathrm{F}$

\section{Diagnosis}

Male sternite VIII (Fig. 2E) with posterior margin rounded. Subgenital plate (Fig. 2F, H) narrow and long. Style (Fig. 2J) broadened on apical two-thirds and tapering towards apex. Aedeagus (Fig. 2K-L) with apex bilobed and with pair of small dorsal spines. Female sternite VII (Fig. 3B-C) with posterior margin slightly excavated medially. First valvula of ovipositor (Fig. 3E) with apex acute.

\section{Etymology}

The species name is in reference to the country of origin of the studied specimens.

\section{Material examined}

\section{Holotype}

BRAZIL - O'; Brasil, RJ [Rio de Janeiro], P. [Parque] N. [Nacional] do Itatiaia, quiosque poço azul;

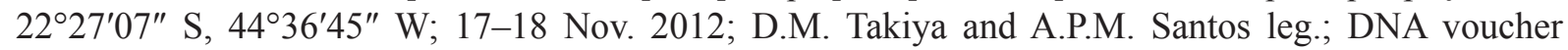
Entomologia, DZRJ ENT 1889; DZRJ-AUCH \#250; DZRJ.

\section{Paratypes}

BRAZIL - Rio de Janeiro • 1 9 ; same collection data as for holotype; DZRJ-AUCH \#251; DZRJ • 1 q ; Itatiaia;Sep.1929;D.Mendesleg.;MNRJ・1 1 ; Itatiaia; alt. 750 m;Jan. 1958; U.Barthleg.; MNRJ・1 9 ;P.N. Itatiaia, Casa do Pesquisador; $22.454^{\circ} \mathrm{S}, 44.608^{\circ} \mathrm{W}$; alt. $800 \mathrm{~m}$; light;27-30 Oct. 2011; R.R. Cavichioli leg.; DZUP-083577 • 1 क; Itatiaia; Oct. 1936; J.F. Zikan leg.; CEIOC • 1 q; same collection data as for preceding; 11 Aug. 1938; CEIOC • 1 \%; same collection data as for preceding; 23 Nov. 1938; CEIOC• 1 q; same collection data as for preceding; 12 Dec. 1939; CEIOC 1 \% ; same collection data as for preceding; 13 Aug. 1940; CEIOC. - Bahia • 1 đo'; Santa Terezinha, Serra Jibóia; $12^{\circ} 51^{\prime} 13^{\prime \prime}$ S, 39²8'32" W; alt. 800 m; luz [light]; 8 Jun. 2007; J.A. Rafael and F.F. Xavier F ${ }^{\circ}$ leg.; INPA • 1 đ̊; Encruzilhada; Nov. 1975; M. Alvarenga leg.; DZUP-083578. - Minas Gerais • 1 §; Itamonte, P.N. do Itatiaia, Travessia Serra Negra, Campo das Flores, segundo acampamento, em árvore; $22^{\circ} 19^{\prime} 55^{\prime \prime} \mathrm{S}, 44^{\circ} 04^{\prime} 42^{\prime \prime} \mathrm{W}$; alt. 1960 m; 25-26 Nov. 2011; D.M. Takiya and A.P.M. Santos leg.; DZRJ-AUCH \#252; DZRJ • 1 o;

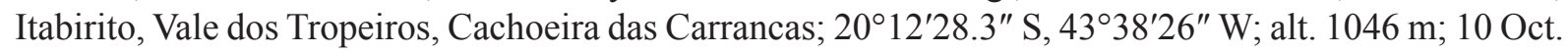
2010; L. Dumas and N. Ferreira Jr. leg.; DZRJ-AUCH \#253; DZRJ • 1 q; São Gonçalo, Rio Abaixo, Est. [Estação] Amb. [Ambiental] Peti-Cemig; 7 Nov. 2003; A.F. Kumagai leg.; DZUP-083579. - Paraná •

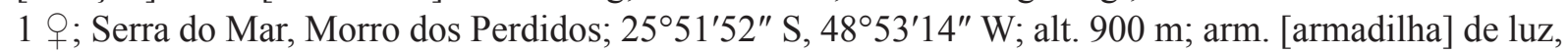
lençol; 17 Feb. 2007; J.A. Rafael and E. Grossi leg.; INPA • 1 đ̃; S. [São] José [dos] Pinhais, BR 277, km 54; luminosa; 23 Mar. 1985; C.I.I.F. [Centro de Identificação de Insetos Fitófagos]; DZUP-083580 •

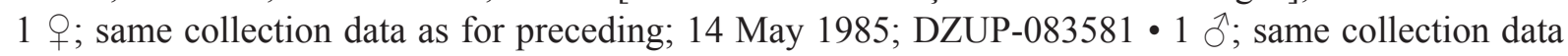



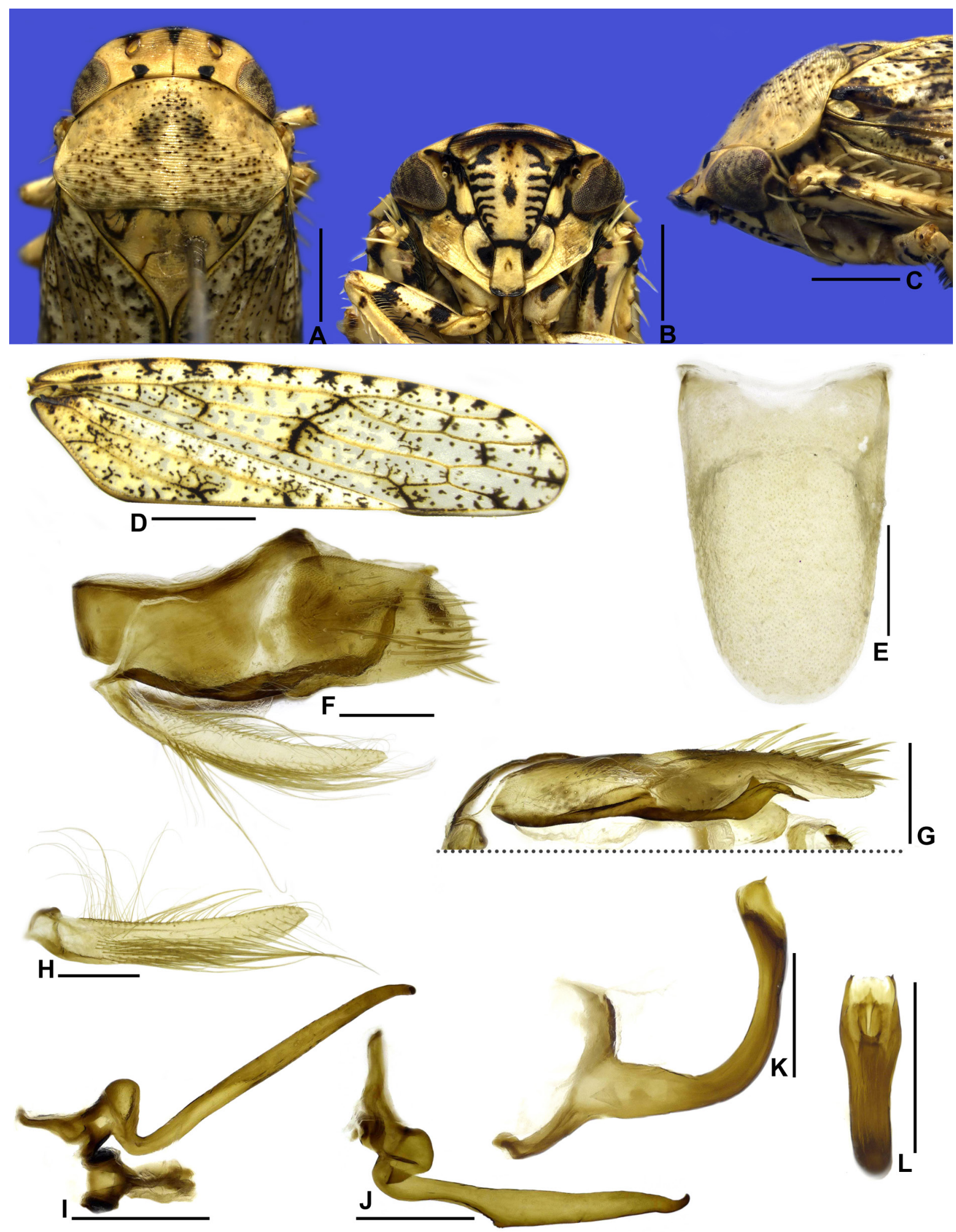

Fig. 2. Fulana brasiliensis gen. et sp. nov., holotype, $\widehat{O}$ (DZRJ). A. Head and thorax, dorsal view. B. Head, ventral view. C. Head and thorax, lateral view. D. Forewing. E. Sternite VIII. ventral view. F. Pygofer, anal tube, valve, and subgenital plate, lateral view. G. Pygofer lobe and anal tube, dorsal view. H. Subgenital plate, ventral view (outer margin at top of figure). I. Style and connective, dorsal view. J. Style, lateral view. K. Aedeagus, lateral view. L. Aedeagus, posterior view. Scale bars: A-C $=1.0 \mathrm{~mm}$; $\mathrm{D}=2.0 \mathrm{~mm} ; \mathrm{E}-\mathrm{L}=0.5 \mathrm{~mm}$. 

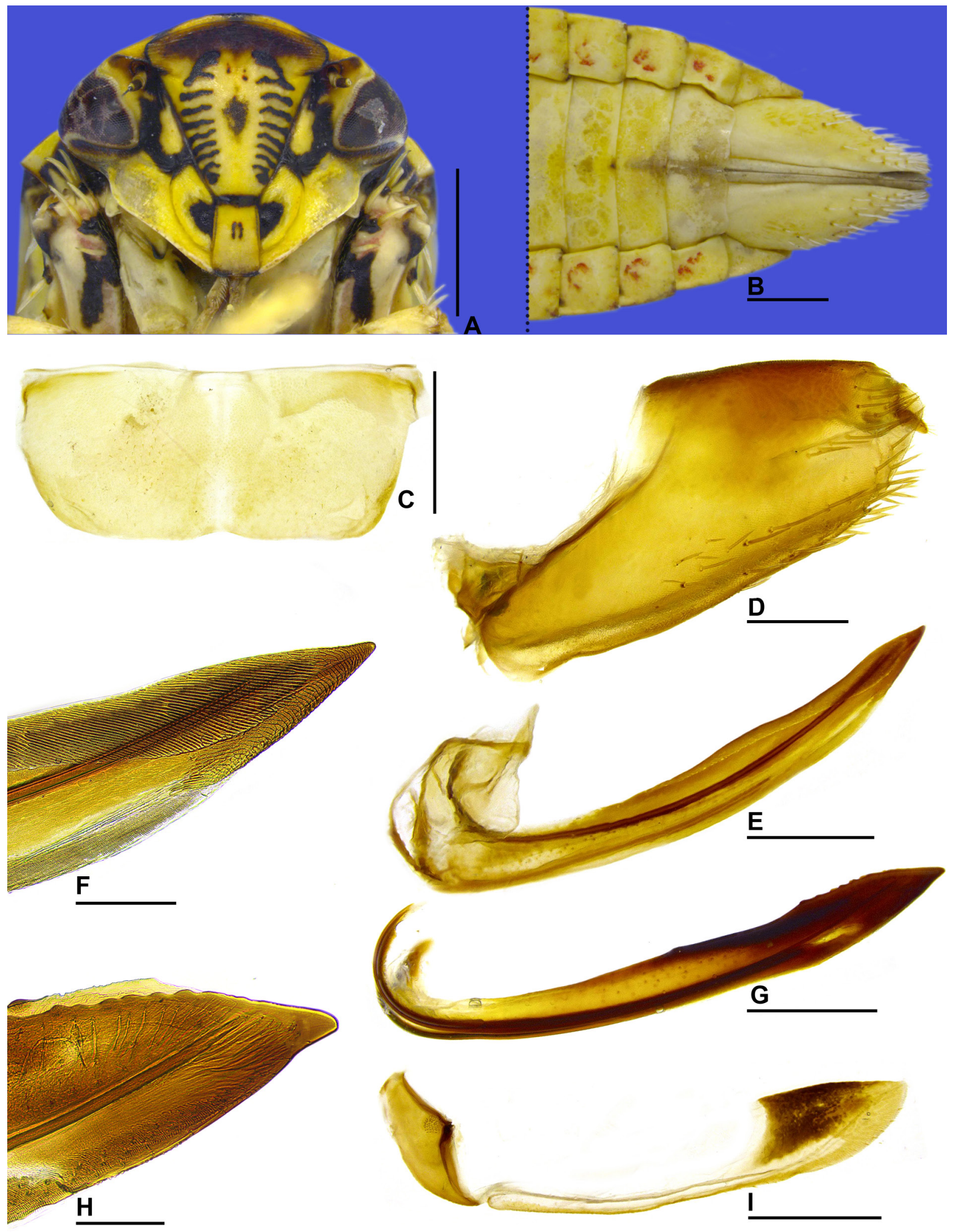

Fig. 3. Fulana brasiliensis gen. et sp. nov., paratype, $q$ (DZRJ-AUCH \#251). A. Head, ventral view. B. Posterior portion of abdomen, ventral view. C. Sternite VII, ventral view. D. Pygofer and anal tube, lateral view. E. First valvifer and first valvula of ovipositor, lateral view. F. Apex of first valvula, lateral view. G. Second valvula of ovipositor, lateral view. H. Apex of second valvula, lateral view. I. Second valvifer and gonoplac, lateral view. Scale bars: A-B $=1.0 \mathrm{~mm}$; $\mathrm{C}-\mathrm{E}, \mathrm{G}, \mathrm{I}=0.5 \mathrm{~mm} ; \mathrm{F}, \mathrm{H}=0.3 \mathrm{~mm}$. 
as for preceding; T.T. [Torre Telepar]; choque; 16-23 May 1985; DZUP-083582 • 1 ऊ̂; same collection data as for preceding; lâmpada; 3 Oct. 1986; Lev. [Levantamento] Ent. [Entomológico] Profaupar; DZUP-083583 • 1 क; same collection data as for preceding; 1 Nov. 1986; DZUP-083584 • 1 क; same collection data as for preceding; 4 Nov. 1986; DZUP-083585 • 1 ; ; same collection data as for preceding; 2 Dec. 1986; DZUP-083586 • 1 §; same collection data as for preceding; 31 Dec. 1986; DZUP-083587 • 1 q; same collection data as for preceding; 19 Jan. 1987; DZUP-083588 1 o ; same collection data as for preceding; 17 Jan. 1988; DZUP-083589 1 đ; same collection data as for preceding; 19 Jan. 1988; DZUP-083590 • 1 đ; Colombo, Embrapa, BR 476, km 20; lâmpada; 18 Jan. 1988; Lev. Ent. Profaupar; DZUP-083591 • 1 đ; Campo Largo, Est. [Estrada] do Cerne, km 45.5; Feb. 1999; L. Chiamolera leg.;

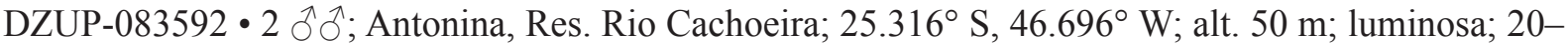
25 Nov. 2014; Entomologia UFPR; DZUP-083593, $083594 \bullet 1$ त; same collection data as for preceding; luminosa solo, 5-10 Nov. 2015; MNRJ • 1 q; Tijucas do Sul, Voçoroca, Excursão Entomologia I, UFPR; 4 Mar. 2015; A.C. Domahovski leg.; MNRJ • 1 đో; Piraquara, Mananciais da Serra; luz; 4 Nov. 2008; P.C. Grossi leg.; MZSP • 1 गे; same collection data as for preceding; $25^{\circ} 29^{\prime} 47^{\prime \prime}$ S, $48^{\circ} 58^{\prime} 54^{\prime \prime}$ W; alt. $1021 \mathrm{~m}$; Arm. [Armadilha] Lum. [Luminosa]; 28 Nov. 2018; A.P. Pinto, B.R. Araujo and A.C. Domahovski leg.; MNRJ • 2 우우 ; same collection data as for preceding; $25.4967^{\circ} \mathrm{S}, 48.9839^{\circ} \mathrm{W}$; alt. 1010 m; malaise; 16 Feb.-11 Mar. 2019; G. Melo and A. Martins leg.; DZUP-083598, DZUP-083599. - Santa Catarina - 1 đ̃; Blumenau, Parque Spitzkopf, confluência dos Ribeirões Caeté e do Ouro, churrasqueira; $20^{\circ} 00^{\prime} 21.60^{\prime \prime} \mathrm{S}, 4^{\circ} 06^{\prime} 45.70^{\prime \prime} \mathrm{W}$; alt. $164 \mathrm{~m}$; pano branco; 21 Jan. 2011; D.M. Takiya and A.P.M. Santos leg.; DZRJ-AUCH \#254, DZRJ. - São Paulo • 1 đ; São Paulo, Alto da Serra; Mar. 1924; R. Spitz leg.; MZSP・ 1 Õ, 1 क ; 43 km a Nordeste de Miracatu; alt. 460 m; 8-9 Oct. 2005; Mielke and Casagrande leg.; MZSP.

\section{Description}

Measurements. Total length: male 10.2-11.5 mm $(\mathrm{n}=21)$; female $12.3-14.5 \mathrm{~mm}(\mathrm{n}=20)$.

Coloration. Pale yellow to yellow (Fig. 6C-F). Crown (Fig. 2A) pale yellow, with circular black spot behind each ocellus, adjacent to posterior margin; anterior margin with three dark maculae, one medially and two in front of ocelli. Face (Figs 2B, 3A) pale yellow to yellow; frons with about ten pairs of dark bands over muscular impressions, dorsal portion with small dark punctuations; epistomal and frontogenal sutures black; lorum with dark subtriangular macula adjacent to lateral margin of clypeus; clypeus with central dark macula and apical margin black; gena with three black maculae that may be interconnected, forming large spot in some specimens: one adjacent to antennal pit, one adjacent to inner corner of compound eye, and one adjacent to lorum base. Pronotum (Fig. 2A) with small dark punctures except near anterior margin, behind eyes. Mesonotum (Fig. 2A) with ringed black maculae near lateral corners; in lateral view (Fig. 2C), lateral lobe of pronotum with large black spot, anepisternum with small black spot. Forewing (Fig. 2D) pale yellow, translucent, with yellow-cream areas on basal twothirds; numerous small black spots throughout surface and several larger black spots on apices of anal veins, along costal margin, over crossveins, and apical margin. Legs (Fig. 6D, F) pale yellow with scattered dark maculae; tarsus of pro- and mesothoracic legs black.

HEAD AND THORAX. External morphological characters as in generic description.

Male terminalia. Sternite VIII (Fig. 2E) strongly produced posteriorly, about 1.6 times as long as wide; lateral margins converging towards apex, posterior margin broadly rounded. Valve subrectangular, three times as wide as long; posterior margin shallowly excavated medially. Pygofer in lateral view (Fig. 2F) elongate, about 2.1 times as long as maximum height; apex rounded; macrosetae distributed only on apical half; basiventral inner process (Fig. 2F) strongly sclerotized, long and thin, almost reaching pygofer apex and contiguous to ventral margin, apical fourth curved dorsally; in ventral view (Fig. 2G), process broadened preapically, with short preapical tooth on external side, apex acute. Subgenital plate 
in lateral view (Fig. 2F) not produced posteriorly as far as pygofer apex; in ventral view (Fig. $2 \mathrm{H}$ ) long and narrow, about 6.4 times longer than wide; lateral margins parallel; apex abruptly rounded. Connective (Fig. 2I) approximately one-fourth of length of style; stalk longer than wide; arms short, slightly wider than stalk; dorsal keel developed. Style in dorsal view (Fig. 2I) with outer lobe developed and rounded; in lateral view (Fig. 2J), broadened on apical two-thirds and tapering towards apex; ventral margin with few denticles at median third; apex acute and curved dorsally. Aedeagus (Fig. 2K-L) with preatrium long; dorsal apodeme projected dorsally; shaft elongated and tubular, curved posterodorsally, expanded apically; apex bilobed, with pair of small apical spines.

Female terminalia. Sternite VII (Fig. 3B-C) 2.3 times as wide as long; posterolateral borders rounded, posterior margin slightly excavated medially. Internal sternite VIII membranous. Pygofer (Fig. 3D) elongate, about 1.8 times as long as maximum height; apex rounded; macrosetae distributed near apex and ventral margin. First valvifer (Fig. 3E) subquadrate. First valvula of ovipositor (Fig. 3E) slightly curved dorsally, about 9.6 times as long as high; with approximately same height along its entire length; dorsal sculptured area beginning on basal third, its apical portion (Fig. 3F) strigate; blade apex acute. Second valvifer (Fig. 3I) higher than long. Second valvula of ovipositor (Fig. 3G) slightly higher apically, approximately 9.5 times longer than maximum height; apical portion (Fig. $3 \mathrm{H}$ ) of dorsal margin with about seven small and rounded teeth; blade apex tapered and acute. Gonoplac (Fig. 3I) 4.7 times as long as high; dorsoapical and ventroapical margins convergent apically; dorsoapical margin short; ventral margin with few short setae mainly near apex; apex subacute.

\section{Remarks}

Male specimens collected from different localities show a variation in the shape of the apical portion of the ventral process of pygofer, which may be more curved or straighter, more dilated or slightly thinner. In addition, some specimens have two conspicuous and rounded black spots over crossveins of discal cells of forewing. However, remaining structures of the male terminalia and shape of the female sternite VII are invariable and we thus consider these variations as intraspecific.

Specimens of Fulana brasiliensis gen. et sp. nov. were mainly collected in areas of Atlantic Forest, at altitudes that vary from 50 to $1960 \mathrm{~m}$ above sea level. A putative second species of the new genus, known only from female specimens from the Brazilian Amazon Rain Forest, State of Amazonas, Manaus, was studied but will not be described until male specimens become available. This undescribed species is similar to F. brasiliensis gen. et sp. nov. in all aspects of the external morphology and female terminalia described herein. However, it can be distinguished by its larger size $(15.5-15.8 \mathrm{~mm})$; head in ventral view with fewer black maculae on face (lorum with small spot adjacent to lateral margin of clypeus, frons with punctuations and a semi-circular macula near anterior margin of crown, and antennal pits black); and sternite VII more deeply excavated medially.

Genus Sicrana gen. nov.

urn:lsid:zoobank.org:act:5D4E6996-37CB-49B3-AF47-0F247BBFF9AA

Figs 4-5, 6G-J

\section{Type species}

Sicrana plana gen. et sp. nov., by present designation and monotypy.

\section{Diagnosis}

Large-sized, flattened leafhoppers (Fig. 6G-J). Head in dorsal view (Fig. 4A) with rugose surface, strongly produced anteriorly, anterior margin parabolic; ocellus closer to median line than to adjacent eye and closer to posterior than to anterior margin of crown; in lateral view (Fig. 4C), with crown- 
face transition distinct and strongly foliaceous, margined by two carinae. Face (Figs 4B, 5A) with frons narrow; maxillary plate not reaching clypeus apex. Pronotum (Fig. 4A-C) with lateral margins foliaceous, expanded laterally. Forewing (Fig. 4D) with appendix absent. Aedeagus (Fig. 4J-K) with pair of apodemal processes. Second valvula of ovipositor with apical portion (Fig. 5G-H) with large preapical tooth.

\section{Etymology}

The generic name is feminine. Sicrana, together with Beltrana and Fulana, forms a very popular expression in Brazil ("Fulana, Sicrana e Beltrana'), which refers to unspecified people or people whose actual names should not be mentioned.

\section{Description}

HEAD AND THORAX. Head in dorsal view (Fig. 4A) moderately produced anteriorly, median length of crown almost as long as interocular width; transocular width three-fourths of humeral width of pronotum; crown with anterior margin parabolic; surface flat; texture rugose; ocellus medium-sized, closer to median line than to adjacent eye and closer to posterior than to anterior margin of crown; coronal suture distinct along basal two-thirds of crown. Head in lateral view (Fig. 4C) with crown-face transition distinct and strongly foliaceous, with two very close carinae; frons tumid. Head in ventral view (Figs 4B, 5A) approximately as wide as high; frontogenal suture strongly sinuous, reaching antennal ledge and distant from eye margin by twice maximum width of clypeus; antennal ledge carinated, strongly arched, adjacent to anterior margin of crown and not extending over frons; frons narrow, approximately two times longer than wide; epistomal suture indistinct; clypeus approximately 1.4 times as long as maximum width, lateral margins parallel, apex slightly emarginated; maxillary plate very narrow, not reaching clypeus apex; gena with ventrolateral margin slightly excavated, texture with several oblique striations parallel to ventrolateral margin. Pronotum (Fig. 4A) rugose, except disc and posterior third with transverse parallel striae; anterior margin almost straight; lateral margins convergent anterad, about two times as long as eye length, rounded, carinated and foliaceous, expanded laterally; posterior margin slightly excavated; in lateral view (Fig. 4C), pronotal surface declivous; head and pronotum in continuous slope. Mesonotum (Fig. 4A) as long as wide; scutellum (Fig. 4C) flat. Forewing (Fig. 4D) long and narrow, approximately 3.2 times as long as wide; venation with some additional crossveins located mainly apically; appendix absent; apex subacute. Profemur with AD, AM, and PD rows reduced and poorly defined, with exception of apical setae $\mathrm{AD}_{1}, \mathrm{AM}_{1}$, and $\mathrm{PD}_{1}$, respectively; $\mathrm{AV}$ and $\mathrm{PV}$ rows formed by 5-6 very short and thin setae; IC row formed by slightly arched comb of fine setae, beginning at distal half of femur and extending to $\mathrm{AM}_{1}$. Protibia in cross-section semi-circular; AV row formed by short setae, slightly longer and thicker towards apex, setae of apical portion shorter than diameter of tibia; $\mathrm{AD}$ row without differentiated setae; PD row with three small setae and undifferentiated intercalary setae; PV row with 4-5 small setae on apical half and undifferentiated intercalary setae. Metafemur with setal formula 2:2:1. Metatibia PD, AD, and AV rows with 24-25, 12, and 16 macrosetae, respectively; metatibia AD row without intercalary setae between macrosetae. Metatarsomere I with two rows of cucullate setae, inner row formed by 5-7 setae, outer row reduced, with 0-2 median setae, apex with 5 platellae. Metatarsomere II apex with 2-3 apical platellae.

Male terminalia. Connective (Fig. 4H) transversely linear. Aedeagus (Fig. 4J-K) with pair of apodemal processes.

Female terminalia. Second valvula of ovipositor (Fig. 5G) slightly higher preapically; apical portion (Fig. 5H) with large preapical tooth. 


\section{Distribution}

Brazil (Rondônia State) and Ecuador (Orellana Province).

\section{Remarks}

Sicrana gen. nov. shares similar characteristics of external morphology and male terminalia with Clinonana Osborn, 1938, for instance: (1) large total length (>13 mm); (2) head distinctly narrower than pronotum; (3) crown with rugose texture; (4) transition crown-face distinct and foliaceous; (5) ocellus closer to median line than to eye and closer to posterior than to anterior margin of crown; (6) pronotum with lateral margins foliaceous, expanded laterally; (7) forewing with subacute apex; and (8) aedeagus with apodemal processes and shaft with apical processes. However, Sicrana gen. nov. can easily be distinguished from Clinonana by the following characteristics: (1) body flattened dorsoventrally (Fig. $6 \mathrm{H}$, J); (2) crown conspicuously more produced anteriorly (Fig. 4A); (3) frontogenal suture strongly sinuous and not reaching the anterior margin of the crown (Figs 4B, 5A); (4) face as high as wide (Figs 4B, $5 \mathrm{~A}$ ); (5) maxillary plate not reaching the apex of the clypeus (Figs 4B, 5A); (6) pronotum with lateral margins rounded (Fig. 4A); (7) forewing without appendix and maculae (Fig. 4D); (8) metafemur with setal formula 2:2:1; and (9) male pygofer without processes (Fig. 4F).

Sicrana plana gen. et sp. nov. urn:lsid:zoobank.org:act:7A4F2853-38B6-41C6-8EFD-DA2DDE7FB3CA

Figs $4-5,6 \mathrm{G}-\mathrm{J}$

\section{Diagnosis}

Male pygofer (Fig. 4F) with dorsal margin strongly excavated; macrosetae located on apical half, forming longitudinal row. Subgenital plate (Fig. 4F-G) ligulate, with tuft of filiform setae near apex on dorsal surface. Style (Fig. 4H-I) with apex acute, more sclerotized and curved outwards. Aedeagus (Fig. 4J-K) with dorsal apodeme with pair of long, claviform processes; shaft tubular with pair of long apical processes directed anteroventrally. Female sternite VII (Fig. 5B-C) with posterior margin with broad median lobe, rounded and emarginated medially.

\section{Etymology}

The species name refers to its flattened body (Fig. 6H, J).

\section{Material examined}

\section{Holotype}

ECUADOR - đ̄; Ecuador, Orellana, Transect Ent. $1 \mathrm{~km} \mathrm{~S}$ of Onkonegare, Reserva Etnica Waorani, Onkonegare Camp; $00^{\circ} 39^{\prime} 10^{\prime \prime} \mathrm{S}, 76^{\circ} 26^{\prime} 00^{\prime \prime} \mathrm{W}$; alt. $220 \mathrm{~m}$; fogging terre [sic! terra] firme forest; $2 \mathrm{Jul}$. 1995; T.L. Erwin et al. leg.; \#1062; DNA voucher Entomologia, DZRJ ENT 2808; EPNC.

\section{Paratypes}

ECUADOR • 1 \%; same collection data as for holotype but 9 Feb. 1995; \#986; EPNC.

BRAZIL • 1 đ’; Brasil, Rondônia, Monte Negro, Reserva Legal, Loteamento; 10¹6'35" S, 6320'40" W; alt. 187 m; light trap; 3-15 Dec. 2011; Amorim, Ament and Riccandi [sic! Riccardi] leg.; DZUP-083603.

\section{Description}

Measurements. Total length: male 13.0-13.7 mm (n=2); female $16.8 \mathrm{~mm}(\mathrm{n}=1)$. 

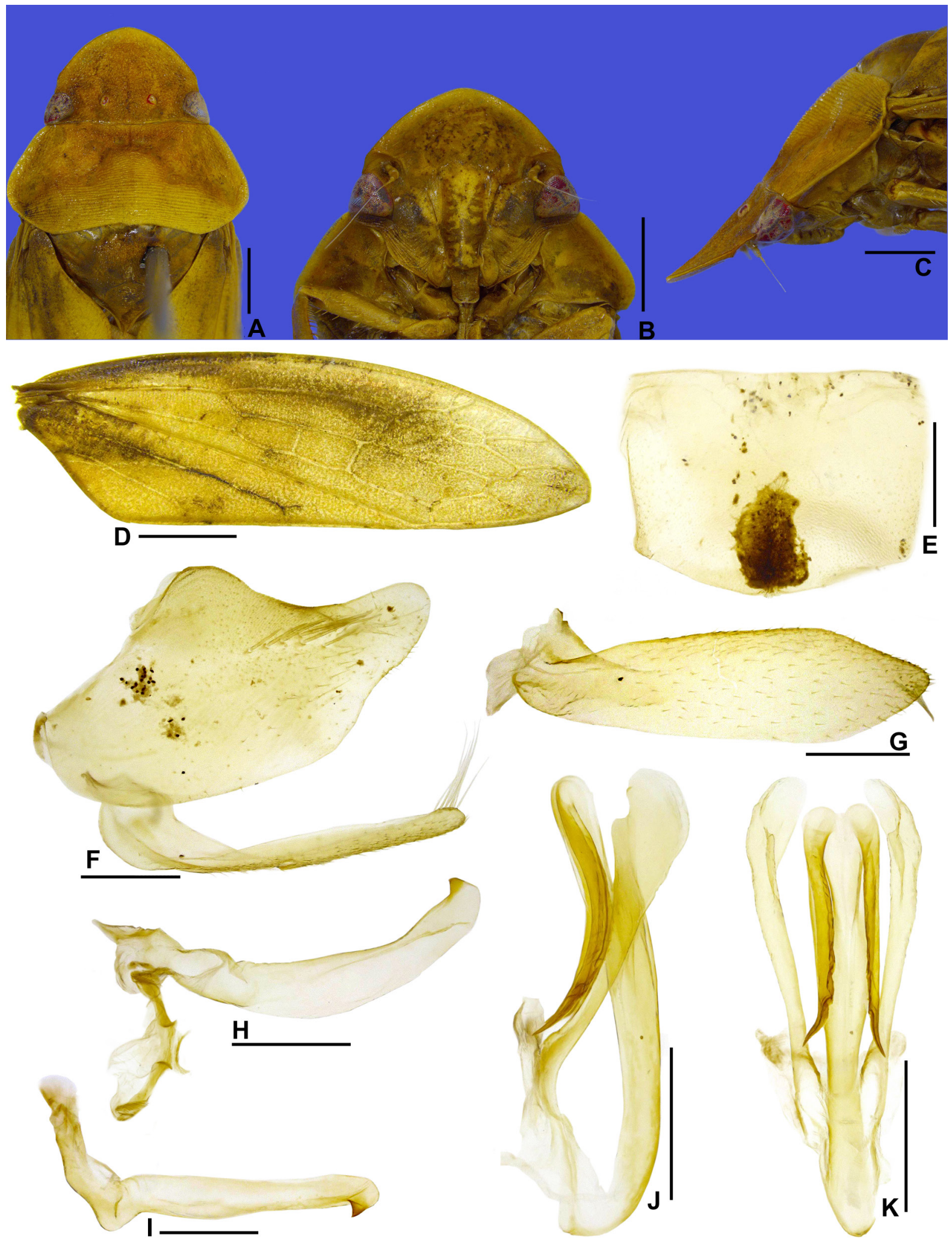

Fig. 4. Sicrana plana gen. et sp. nov., holotype, ồ (EPNC). A. Head and thorax, dorsal view. B. Head, ventral view. C. Head and thorax, lateral view. D. Forewing. E. Sternite VIII, ventral view. F. Pygofer, valve, and subgenital plate, lateral view. G. Subgenital plate, ventral view (outer margin at top of figure). H. Style and connective, dorsal view. I. Style, lateral view. J. Aedeagus, lateral view. K. Aedeagus, posterior view. Scale bars: $\mathrm{A}-\mathrm{C}=1.0 \mathrm{~mm} ; \mathrm{D}=2.0 \mathrm{~mm}$; $-\mathrm{K}=0.5 \mathrm{~mm}$. 

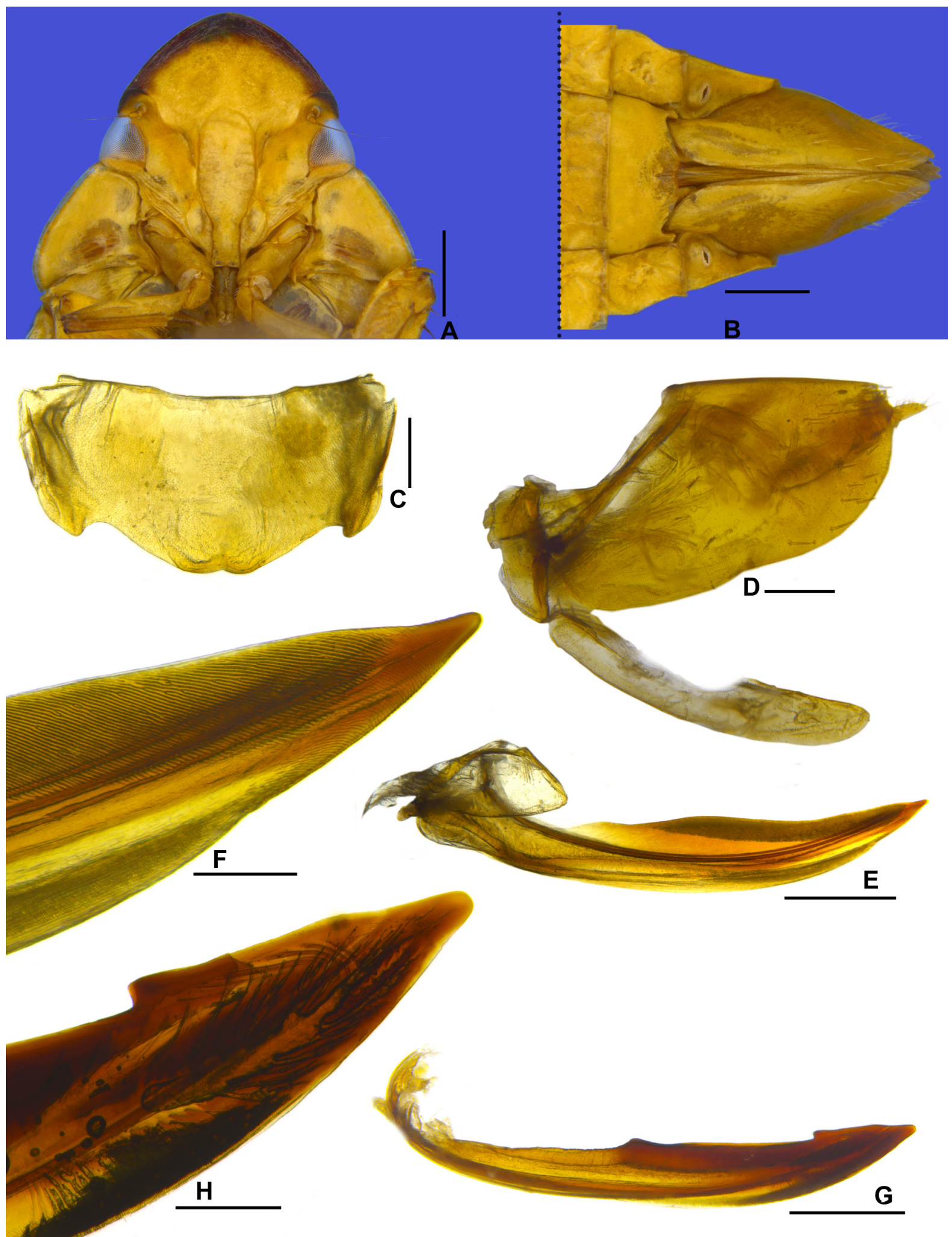

Fig. 5. Sicrana plana gen. et sp. nov., paratype, $q$ (EPNC). A. Head, ventral view. B. Posterior portion of abdomen, ventral view. C. Sternite VII, ventral view. D. Pygofer, second valvifer, gonoplac, and anal tube, lateral view. E. First valvifer and first valvula of ovipositor, lateral view. F. Apex of first valvula, lateral view. G. Second valvula of ovipositor, lateral view. H. Apex of second valvula, lateral view. Scale bars: $\mathrm{A}-\mathrm{B}=1.0 \mathrm{~mm}$; $\mathrm{C}-\mathrm{E}, \mathrm{G}=0.5 \mathrm{~mm} ; \mathrm{F}, \mathrm{H}=0.3 \mathrm{~mm}$. 
Coloration. Male yellow (Fig. 6G-J) without markings. Female with face (Fig. 5A) with dark band adjacent to margin of crown.

HEAD AND THORAX. External morphological characters as in generic description.

Male terminalia. Sternite VIII (Fig. 4E) subrectangular, about 1.3 times as wide as long; lateral margins parallel, posterior margin slightly rounded. Valve subrectangular, 2.3 times as wide as long; posterior margin convex. Pygofer in lateral view (Fig. 4F) moderately produced posteriorly, about 1.7

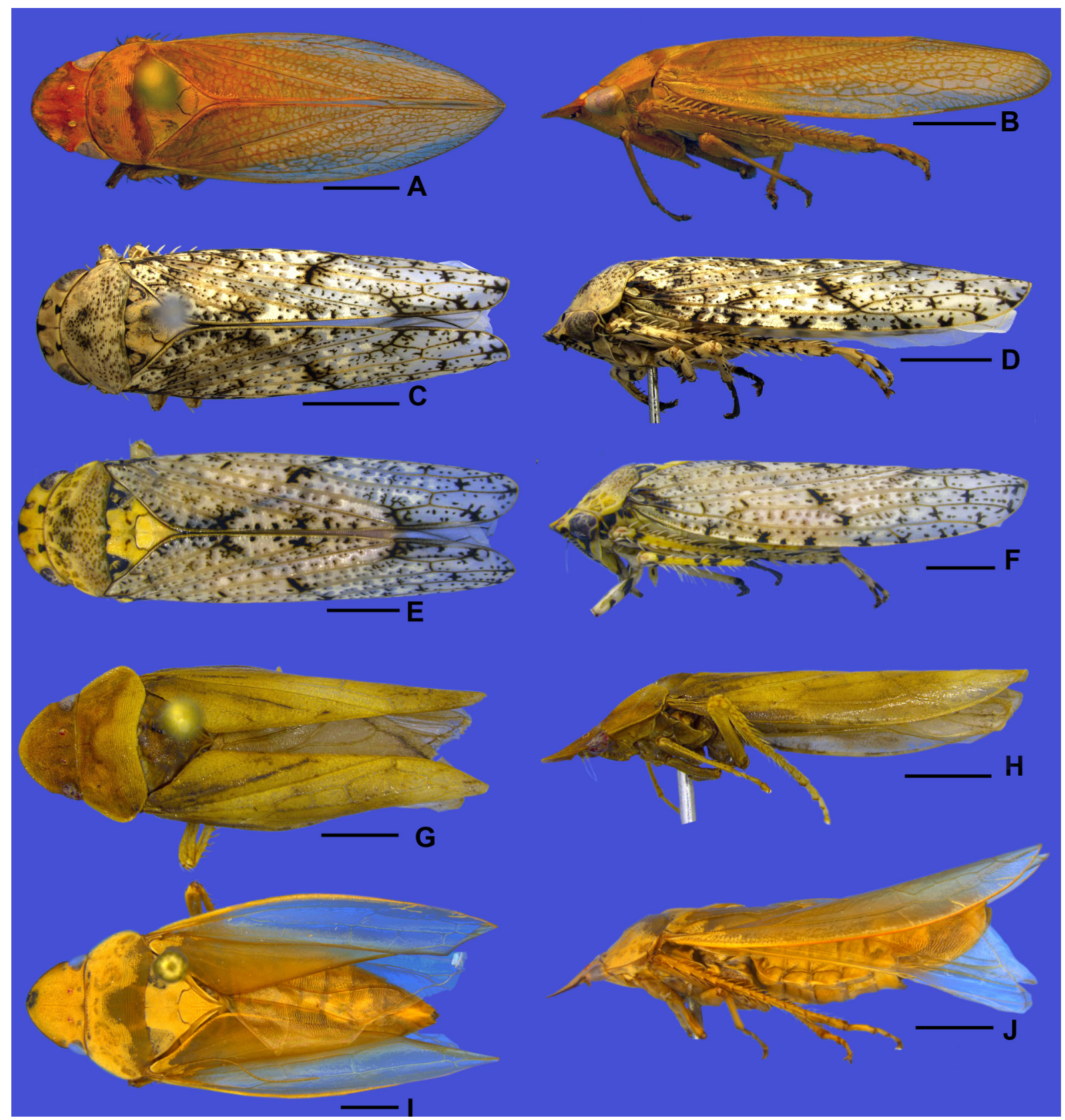

Fig. 6. Habitus of type specimens, dorsal and lateral view, respectively. A-B. Beltrana reticulata gen. et sp. nov., holotype, $\widehat{\partial}$ (USNM). - C-D. Fulana brasiliensis gen. et sp. nov., holotype, $\widehat{\partial}$ (DZRJ). - E-F. Fulana brasiliensis, paratype + (DZRJ-AUCh \#251). G-H. Sicrana plana gen. et sp. nov., holotype, ô (EPNC). - I-J. Sicrana plana gen. et sp. nov., paratype, o (EPNC). Scale bars: $2.0 \mathrm{~mm}$. 
times as long as maximum height, without processes; dorsal margin strongly excavated; less than 10 macrosetae forming a longitudinal row, near dorsal margin of apical half; apex tapered and rounded. Subgenital plate, in lateral view (Fig. 4F), produced posteriorly as far as pygofer apex; in ventral view (Fig. 4G), ligulate, about 3.6 times as long as wide; ventral surface covered by small setae; dorsal surface with tuft of moderately long filiform setae near apex; lateral margins divergent towards apex; apex abruptly tapered and rounded. Connective (Fig. 4H) with anterior portion membranous, posterior portion sclerotized; approximately one-seventh length of style; arms narrow, strongly divergent. Style in dorsal view (Fig. 4H) with outer lobe poorly developed; in lateral view (Fig. 4I), with margins parallel; ventral margin smooth; apex acute, more sclerotized and curved outwards. Aedeagus (Fig. 4J-K) with preatrium absent; atrium expanded posteriorly; dorsal apodeme well developed; apodemal processes claviform, extending to apex of shaft, subapical region of each process rounded and with preapical excavation dorsally; shaft elongated and tubular, curved dorsally; apex with pair of processes parallel to shaft, extending anteroventrally, half-length of shaft, each process with inner margin crenulate and apex acute.

Female terminalia. Sternite VII (Fig. 5B-C) 2.3 times as wide as long; posterolateral angles developed and subacute; posterior margin with broad median lobe, rounded and emarginated medially. Internal sternite VIII membranous. Pygofer (Fig. 5D) elongate, about 1.5 times as long as maximum height; apex rounded; few macrosetae distributed near apex and ventral margin. First valvifer (Fig. 5E) subtriangular. First valvula of ovipositor (Fig. 5E) slightly curved dorsally; about seven times as long as high; slightly higher on median third; dorsal sculptured area beginning at basal third; apex (Fig. 5F) with dorsal and ventral sculptured areas strigate; blade apex acute. Second valvifer (Fig. 5D) higher than long. Second valvula of ovipositor (Fig. 5G) slightly higher medially; approximately 7.5 times as long as maximum height; median third with dorsal triangular protuberance; apical portion (Fig. $5 \mathrm{H}$ ) with large preapical tooth; blade apex tapered and acute. Gonoplac (Fig. 5D) 5.4 times as long as high; dorsoapical margin long and straight; apex rounded.

\section{Taxonomic notes}

\section{Genus Marganana DeLong, 1948}

Margana DeLong, 1942: 109; pls 1, 24, 28, 32, 34 (type species: Ponana marginifrons var. suilla Ball, 1935). [Preoccupied name]

Marganana DeLong, 1948: 101. [New name for Margana].

Freytagana DeLong, 1975: 409; figs 1-8 (type species: Freytagana gibsoni DeLong, 1975). Syn. nov.

\section{Marganana (Marganana) mexicana DeLong \& Freytag, 1963}

Fig. 7

Marganana (Marganana) mexicana DeLong \& Freytag, 1963: 260, pl. I fig. 4, pl. II figs 6-11, 24. Freytagana gibsoni DeLong, 1975: 409; figs 1-8. Syn. nov.

\section{Material examined}

Holotype

MEXICO - J; Mexico, Puebla, Necaxa; 27 Oct. 1945; DeLong, Hershberger, Stone and Elliot leg.; OSUC-0169614.

\section{Other material}

MEXICO • $\widehat{~}$, holotype of Freytagana gibsoni; Mexico, Rte. 190, 28 mi. E of Mexico City; 28 Jul. 1965; P.H. Freytag and L.P. Gibson leg.; OSUC-0158615. 


\section{Remarks}

Margana was erected by DeLong (1942) to accomodate the type species, Ponana marginifrons var. suilla Ball, 1935, from Arizona, USA. A few years later, DeLong (1948) proposed a new name for the genus, Marganana, because the previous name had already been taken by a genus of Lepidoptera Linnaeus, 1758. DeLong \& Freytag (1963) erected a new subgenus, Declivana and two new species, Marganana (Marganana) mexicana from Mexico and Marganana (Declivana) equata from Guyana.
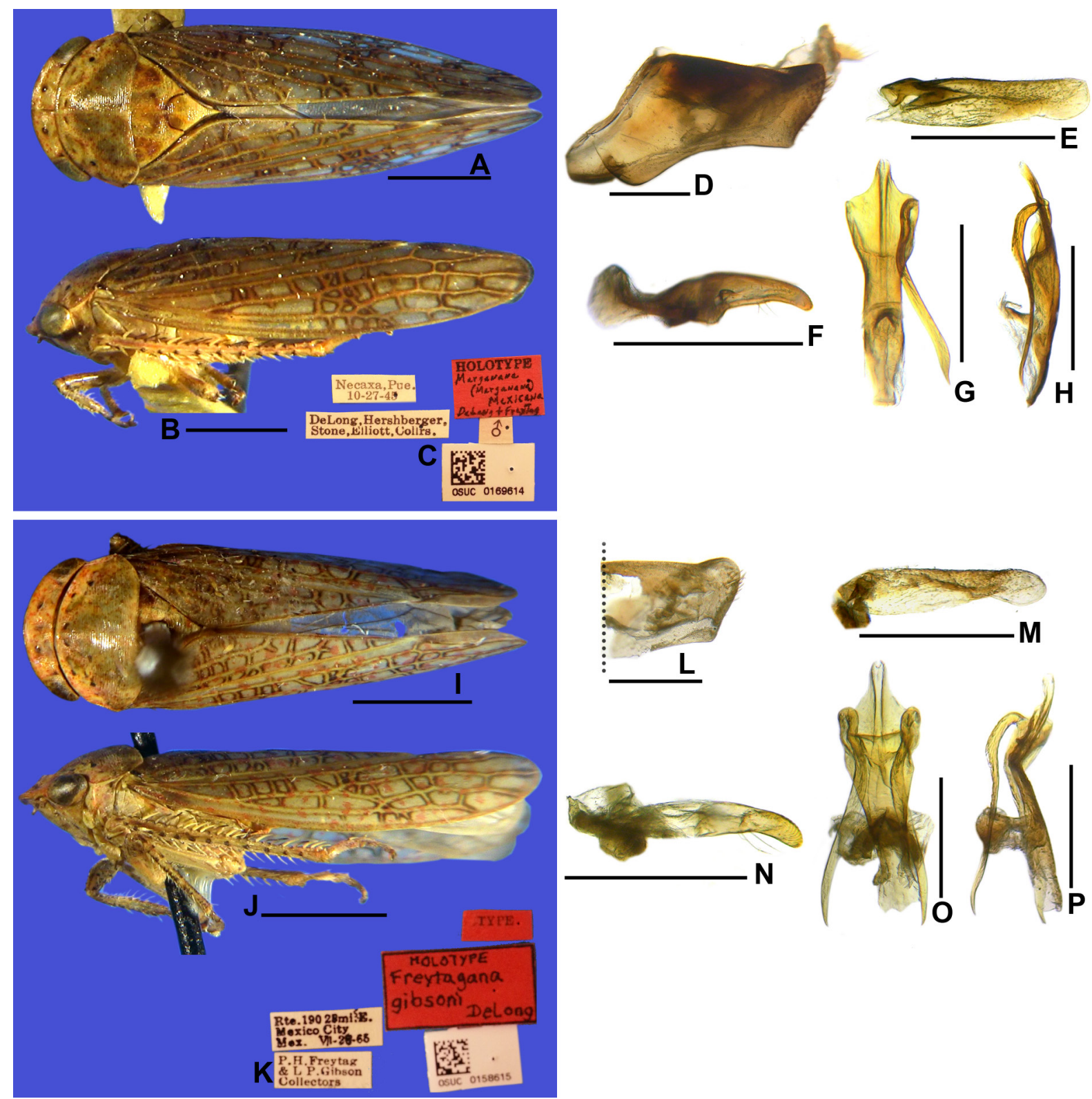

Fig. 7. Marganana (Marganana) mexicana DeLong \& Freytag, 1963. A-H. Holotype, § (OSUC-0169614). A. Dorsal habitus. B. Lateral habitus. C. Labels. D. Pygofer, valve, and anal tube, lateral view. E. Subgenital plate, ventral view. F. Style, lateral view. G. Aedeagus, posterior view. H. Aedeagus, lateral view. - I-P. §̂, holotype of Freytagana gibsoni DeLong, 1975 (OSUC-0158615). I. Dorsal habitus. J. Lateral habitus. K. Labels. L. Apical portion of pygofer, lateral view. M. Subgenital plate, ventral view. N. Style, lateral view. O. Aedeagus, posterior view. P. Aedeagus, lateral view. Scale bars: A-B, I-J=2.0 mm; D-H, L-P=0.5 mm. 
According to DeLong (1942) and DeLong \& Freytag (1963), Marganana differs from other Gyponini genera by the following characteristics: (1) crown short and broad, with transversely striated surface; (2) ocellus closer to median line than to adjacent eye; (3) transition crown-face with thickened margin and carinate; (4) face short and broad; (5) pronotum broad and slightly wider than head; (6) forewing long and narrow, with venation normal to reticulated, with veins wide, conspicuous, and dark margined, and appendix developed; (7) hind tibia without outer secondary setae; and (8) aedeagus simple, without basal processes.

The monotypic genus Freytagana was erected by DeLong (1975) to accomodate the type species, Freytagana gibsoni DeLong, 1975, from Mexico. According to that author, Freytagana differs from other gyponines by the following set of characteristics: (1) crown short and broad, with anterior and posterior margins almost parallel; (2) ocellus closer to median line than to adjacent eye; (3) transition crown-face distinct and thick; and (4) forewing long and narrow, with venation reticulated, and slight appendix.

Based on the original descriptions of the genera and a detailed study of the holotypes of the two included species, we conclude that there are no characters that distinguish Freytagana from Marganana. Therefore, we suggest that Freytagana be treated as a junior synonym of Marganana. In addition, considering the distribution data (the holotype of F. gibsoni and several paratypes of M. mexicana are from the same locality - Mexico City), forewing venation, and male terminalia (Fig. 7A-H, I-P), we concluded that holotypes of $F$. gibsoni and M. mexicana are conspecific, so that the former should be treated as a junior synonym of the latter. We note that the holotype of $F$. gibsoni has its aedeagus shaft damaged and twisted, besides being strongly bent ventrally at apical half. This may be the reason why DeLong did not treat them as the same species.

Genus Chilella DeLong \& Freytag, 1967

Chilella DeLong \& Freytag, 1967: 112; pl. I fig. 2, pl. III fig. 45 (type species: Chilella rugella DeLong \& Freytag, 1967).

Chilella rugella DeLong \& Freytag, 1967

Fig. 8

\section{Material examined}

\section{Holotype}

CHILE • ${ }_{+}$; Chile, Sin. Hem.; 1956; E.C. Reed and C.J. Drake leg.; USNM.

\section{Remarks}

The monotypic genus Chilella was erected by DeLong \& Freytag (1967) based on a single female specimen of Chilella rugella DeLong \& Freytag, 1967 from Chile. According to the authors, Chilella differs from other genera of Gyponini by the following set of characteristics: (1) crown short and broad; (2) transition crown-face rounded, without defined margin; (3) ocelli distant from eyes, located on anterior portion of crown; (4) forewing rugose, corrugated and without an appendix; and (5) foreleg with metatibia intercalary setae between macrosetae.

Our study of the holotype of Chilella rugella (Fig. 8A-E) indicated that the position of the ocelli, which are located in the crown-face transition, is incongruent with the diagnoses proposed for Gyponini by DeLong (1942), Oman (1949), Linnavuori (1959), Dietrich (2005), and Krishnankutty et al. (2016). According to those authors, the ocelli in Gyponini are located on the crown, away from the anterior margin. Moreover, according to the key to the tribes of Iassinae proposed by Krishnankutty et al. (2016), Chilella rugella is classified as Selenomorphini Evans, 1974, based on the following characteristics: 
(1) head with crown poorly delimited, rounded to face; (2) hind wing veins R4+5 and M1+2 separated distally, not confluent at apex; and (3) body pigmentation primarily pale green or stramineous.

However, morphological characteristics of C. rugella are not congruent with any genera currently included in Selenomorphini. Chilella differs from Selenomorphus Evans, 1974 and Linnavuoria Dai \& Dietrich, 2015 in having the crown-face transition indistinct, whereas in the last two genera the crownface transition is distinctly angulated in profile. Also, Chilella differs from Pachyopsis Uhler, 1877 and Uhleriana Domahovski, 2019 in having the metatibiae with intercalary setae. In addition, it differs from Parapachyopsis Domahovski, 2019 in having the head narrower than the pronotum and from Scaroidana Osborn, 1938 by its smaller size $(9.0 \mathrm{~mm})$ and position of the ocelli mesad to the antennal pits (Fig. 8C), whereas in Scaroidana they are closer to the eyes and located above the antennal pits, in ventral view.

Unfortunately, the holotype of C. rugella lost its forewings, which could have provided useful information about its relationships with other genera of Selenomorphini. However, according to DeLong \& Freytag (1967), the forewings are rugose and corrugated, two features not found in any other genus of the tribe. We propose the transfer of Chilella to Selenomorphini, maintaining it as a valid genus. However, the discovery of male specimens as well as phylogenetic studies on the tribe are necessary to confirm our proposal.

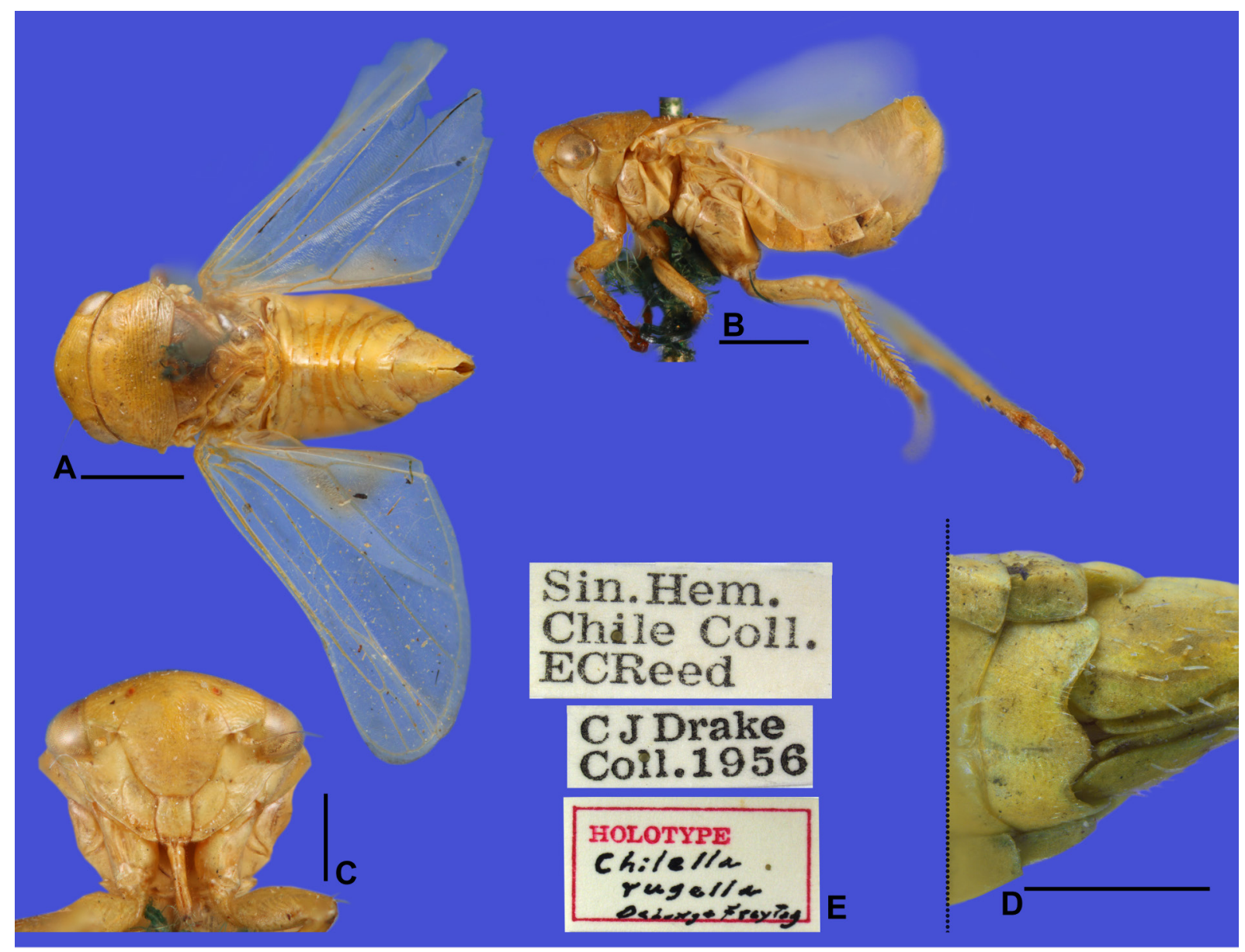

Fig. 8. Chilella rugella DeLong \& Freytag, 1967, holotype, $q$ (USNM). A. Habitus, dorsal view. B. Habitus, lateral view. C. Head, ventral view. D. Posterior portion of abdomen, ventrolateral view. E. Labels. Scale bars: A-B=2.0 mm; C-D =1.0 mm. 


\section{Discussion}

In this study, three new species of Gyponini from South America were described and illustrated. These species have morphological characteristics that are clearly not in accordance with the diagnoses of previously established genera of the tribe. Therefore, three new genera were erected to allocate them. Holotypes of Marganana (Marganana) mexicana DeLong \& Freytag, 1963 and Freytagana gibsoni DeLong, 1975 were studied and we concluded that they are conspecific. Therefore, F. gibsoni is regarded as a junior synonym of M. mexicana, and the monotypic genus Freytagana DeLong, 1975 is regarded as a junior synonym of Marganana DeLong, 1948. In addition, our study of the holotype of Chilella rugella DeLong \& Freytag, 1967, the only species so far described for the genus, showed that the position of the ocelli, which are located at the crown-face transition, is incongruent with the condition observed in the Gyponini; in the latter group, the ocelli are consistently located on the crown. This feature, added to the shape of the crown, the venation of the hind wings, and body color, supports the transfer of Chilella to Selenomorphini. With the new genera described here and the proposed taxonomic changes, the Gyponini now comprise 72 genera and 1406 valid species. Many species from the Neotropical region remain undescribed, especially from poorly known and threatened biomes such as the Amazon Forest.

Of the 72 genera currently recognized in the Gyponini, 20 are monotypic. Approximately $70 \%$ of the species of the tribe are included in only six genera, viz., Gypona Germar, 1821, Curtara DeLong \& Freytag, 1972, Polana DeLong, 1942, Ponana Ball, 1920, Gyponana Ball, 1920, and Darma Walker, 1858. The present work contributes to our knowledge of the morphological diversity within this interesting leafhopper tribe.

\section{Acknowledgments}

The study of type specimens of previously described species was made possible through specimen loans and lab equipment shared by Luciana Musetti and Hans Klompen (OSU), Stuart McKamey (USNM), and Christopher Dietrich (INHS). Specimens described herein were made available through loans by C. Dietrich, Jason Cryan (Natural History Museum of Utah), Márcio Felix (CEIOC), Marcio Oliveira (INPA), and Rodney Cavichioli (DZUP). Terry Erwin, Michael Pogue, and Warren Steiner (USNM) provided access to the Smithsonian Institution Ecuadorian rainforest canopy fogging samples to C. Dietrich. We are grateful to James Zahniser (USDA) for producing images of the abdomen and labels of the holotype of C. rugella. This study was mainly developed during CCG doctoral work at Programa de Pós-graduação em Zoologia, Universidade Federal do Rio de Janeiro, which was supported by a Coordenação de Aperfeiçoamento de Pessoal de Nível Superior (CAPES - finance code 001) stipend. CCG is currently a post-doctoral fellow from Fundação Carlos Chagas Filho de Amparo à Pesquisa do Estado do Rio de Janeiro (FAPERJ, proc. E-26/202.301/2019). ACD receives a doctoral stipend from Conselho Nacional de Desenvolvimento Científico e Tecnológico (CNPq, proc. 140815/2017-1). DMT is a research productivity fellow from CNPq (proc. 313677/2017-4) and a Cientista do Nosso Estado fellow from FAPERJ (proc. E-26/202.672/2019). This work was partially supported by a grant from FAPERJ to GM (proc. E-26/200.082/2019, Apoio Emergencial ao Museu Nacional). GM is a research productivity fellow from CNPq (proc. 303229/2018-7).

\section{References}

Cavichioli R.R. \& Takiya D.M. 2012. Description of a new species of Wolfniana and new records of Rotigonalia (Hemiptera: Cicadellidae: Cicadellinae) from the state of Amazonas, Brazil. Zoologia 29 (1): 85-88. https://doi.org/10.1590/S1984-46702012000100011

DeLong D.M. 1942. A Monographic Study of the North American Species of the Subfamily Gyponinae (Homoptera-Cicadellidae) Exclusive of Xerophloea. Ohio State University, Columbus. 
DeLong D.M. 1948. A proposed new genus name Marganana and the allotype description of Prairiana hirsuta DeL. - Gyponinae (Homoptera: Cicadellidae). Ohio Journal of Science 48 (3): 101.

DeLong D.M. 1975. A new genus Freytagana, and new species of Mexican Gyponinae (Homoptera: Cicadellidae). Ohio Journal of Science 48 (3): 409-410.

DeLong D.M. \& Freytag P.H. 1963. Studies of the Gyponinae 1. The genus Marganana DeLong (Homoptera: Cicadellidae). Ohio Journal of Science 63 (6): 258-262.

DeLong D.M. \& Freytag P.H. 1964. Four genera of the World Gyponinae: a synopsis of the genera Gypona, Gyponana, Rugosana and Reticana. Bulletin of the Ohio Biological Survey 2 (3): 1-227.

DeLong D.M. \& Freytag P.H. 1967. Studies of the Gyponinae: two new genera, Chilenana and Chilella. Ohio Journal of Science 67 (2): 105-112.

Dietrich C.H. 2005. Keys to the families of Cicadomorpha and subfamilies and tribes of Cicadellidae (Hemiptera: Auchenorrhyncha). Florida Entomologist 88: 502-517.

https://doi.org/10.1653/0015-4040(2005)88[502:KTTFOC]2.0.CO;2

Domahovski A.C. \& Cavichioli R.R. 2018. Two new remarkable genera and two new species of Gyponini (Hemiptera: Cicadellidae: Iassinae) from Brazil. European Journal of Taxonomy 476: 1-17. https://doi.org/10.5852/ejt.2018.476

Domahovski A.C. \& Cavichioli R.R. 2020. Three new species of Polana (Varpulana) (Hemiptera: Cicadellidae: Gyponini) from Brazil, with updated key to males and taxonomic notes on the female genitalia. Zootaxa 4767 (4): 501-517. https://doi.org/10.11646/zootaxa.4767.4.1

Domahovski A.C. \& Cavichioli R.R. 2021. Magnana, a new genus of Gyponini from Southeastern Brazil (Hemiptera: Cicadellidae: Iassinae). Papéis Avulsos de Zoologia 61: e20216140: 1-5. https://doi.org/10.11606/1807-0205/2021.61.40

Domahovski A.C., Gonçalves C.C., Takiya D.M. \& Cavichioli R.R. 2020. Description of two new species of Regalana and a new genus of Gyponini (Hemiptera: Cicadellidae: Iassinae). Zootaxa 4731 (1): 89102. https://doi.org/10.11646/zootaxa.4731.1.6

Freytag P.H. 2020. A new species of Acusana from French Guiana (Hemiptera: Cicadellidae: Gyponinae). Entomological News 129 (1): 1-5. https://doi.org/10.3157/021.129.0101

Gonçalves C.C. 2016. Análise filogenética de Gyponini Stål, 1870 (Insecta: Hemiptera: Cicadellidae: Iassinae). PhD Thesis, Museu Nacional, Universidade Federal do Rio de Janeiro, Rio de Janeiro.

Hamilton K.G.A. 1981. Morphology and evolution of the rhynchotan head (Insecta: Hemiptera, Homoptera). Canadian Entomologist 113 (11): 953-974. https://doi.org/10.4039/Ent113953-11

Krishnankutty S.M., Dietrich C.H., Dai W. \& Siddappaji M.H. 2016. Phylogeny and historical biogeography of leafhopper subfamily Iassinae (Hemiptera: Cicadellidae) with a revised tribal classification based on morphological and molecular data. Systematic Entomology 41 (3): 580-595. https://doi.org/10.1111/syen.12175

Linnavuori R. 1959. Revision of the Neotropical Deltocephalinae and some related subfamilies (Homoptera). Annales Zoologici Societatis Zoologicae Botanicae 'Vanamo’20: 1-370.

Mejdalani G. 1993. Morfologia da cabeça de Versigonalia ruficauda (Walker, 1851), com notas sobre a terminologia (Homoptera, Cicadellidae, Cicadellinae). Revista Brasileira de Entomologia 37 (2): 279-288. 
Mejdalani G. 1998. Morfologia externa dos Cicadellinae (Homoptera, Cicadellidae): comparação entre Versigonalia ruficauda (Walker) (Cicadellini) e Tretogonia cribrata Melichar (Proconiini), com notas sobre outras espécies e análise da terminologia. Revista Brasileira de Zoologia 15: 451-544. https://doi.org/10.1590/S0101-81751998000200015

Oman P.W. 1949. The Nearctic leafhoppers (Homoptera: Cicadellidae). A generic classification and check list. Memoirs of the Entomological Society of Washington 3: 1-253.

Rakitov R.A. 1997. On differentiation of cicadellid leg chaetotaxy (Homoptera: Auchenorrhyncha: Membracoidea). Russian Entomological Journal 6: 7-27.

Young D.A. 1968. Taxonomic study of the Cicadellinae (Homoptera: Cicadellidae), Part 1, Proconiini. Bulletin of the United States National Museum, 261: 1-287. https://doi.org/10.5962/bhl.part.20869

Young D.A. 1977. Taxonomic study of the Cicadellinae (Homoptera: Cicadellidae). Part 2. New World Cicadellini and the genus Cicadella. Bulletin of North Carolina Agricultural Experiment Station 239: $1-1135$.

Zanol K.M.R. 1988. Morfologia de Neophlepsius gracilis (Osborn, 1923) (Homoptera, Cicadellidae, Deltocephalinae). Revista Brasileira de Entomologia 32 (1): 69-93.

Manuscript received: 19 October 2020

Manuscript accepted: 3 March 2021

Published on: 18 May 2021

Topic editor: Nesrine Akkari

Section editor: Christopher H. Dietrich

Desk editor: Kristiaan Hoedemakers

Printed versions of all papers are also deposited in the libraries of the institutes that are members of the EJT consortium: Muséum national d'histoire naturelle, Paris, France; Meise Botanic Garden, Belgium; Royal Museum for Central Africa, Tervuren, Belgium; Royal Belgian Institute of Natural Sciences, Brussels, Belgium; Natural History Museum of Denmark, Copenhagen, Denmark; Naturalis Biodiversity Center, Leiden, the Netherlands; Museo Nacional de Ciencias Naturales-CSIC, Madrid, Spain; Real Jardín Botánico de Madrid CSIC, Spain; Zoological Research Museum Alexander Koenig, Bonn, Germany; National Museum, Prague, Czech Republic. 